\title{
Production Potential and Forage Quality of Cereal-Legume Intercropping Systems in Cauvery Command Area of Karnataka
}

\author{
K.N. Manoj ${ }^{1}$, B.G. Shekara ${ }^{2}$ and D. Shoba ${ }^{3}$ \\ ${ }^{1}$ Department of Agronomy, UAS, GKVK, Bengaluru-560 065, India \\ ${ }^{2}$ AICRP on Forage Crops, ZARS, V. C. Farm, Mandya-571 405, India \\ ${ }^{3}$ AICRP on Maize, ZARS, V. C. Farm, Mandya-571 405, India \\ *Corresponding author
}

\section{A B S T R A C T}

\begin{tabular}{l} 
Ke y w o r d s \\
$\begin{array}{l}\text { Forage yield, } \\
\text { Cereal-legume, } \\
\text { Chemical } \\
\text { composition, } \\
\text { Intercropping, } \\
\text { Quality yield }\end{array}$ \\
Article Info \\
\hline $\begin{array}{l}\text { Accepted: } \\
26 \text { April } 2020 \\
\text { Available Online: } \\
\text { 10 May } 2020\end{array}$ \\
\hline
\end{tabular}

A field experiment was conducted during kharif season of 2018 at Zonal Agricultural Research Station, Vishweswaraiah Canal Farm, Mandya to study the productivity and quality of different cereal-legume intercropping systems. The treatments consist of three intercropping systems viz., maize + cowpea (3:1), sorghum + cowpea (3:1) and bajra Napier hybrid + cowpea (2:8) and four sole crops like maize, sorghum, bajra Napier hybrid and cowpea. Among different treatments, higher green fodder yield (552.17 q/ha), dry fodder yield (110.37 q/ha), crude fodder yield (19.59 q/ha), total digestible crude fodder yield $(18.33 \mathrm{q} / \mathrm{ha})$, ash yield $(12.73 \mathrm{q} / \mathrm{ha})$, fat yield (3.33 q/ha), fibre yield (30.78 q/ha) and carbohydrate yield (29.46 q/ha) were noticed in bajra Napier hybrid + cowpea system. The higher content of crude protein was observed in sole cowpea $(20.5 \%)$ while higher dry matter $(22.97 \%)$, fibre $(34.17 \%)$ and carbohydrate $(34.43 \%)$ content were observed in sole sorghum compared to other treatments. Bajra Napier hybrid + cowpea performed well both quality and quantity wise and can be a best system.

\section{Introduction}

Livestock production is the keystone of Indian agriculture and plays an important role in providing employment especially in rural areas. Fodders as a group of crops generally that differ from normal food and commercial crops as they are primarily grown for the fresh vegetative biomass. The fodder supply situation in India is extremely precarious and the gap is very wide. India has $15 \%$ of world cattle population and there is tremendous pressure of livestock on available feed and fodder, as land available for fodder production has been decreasing. Presently, it is estimated that only $4.4 \%$ of the total 
cropped area is devoted to fodder production. Feed and fodder cost constitute about 60-70 $\%$ of cost of milk production, thus cultivated fodder has an important role in meeting requisite of various nutrients and roughage in our country to produce milk and is most economical as compared to concentrates.

In India, there is no practice of fodder production in rural areas and generally animals consume naturally grown grasses and shrubs which are of low quality in terms of protein and available energy, they are thus heavily dependent on seasonal variations and this results in fluctuation in fodder supply affecting supply of milk round the year. Cereal fodder crops such as maize, sorghum, pearl millet, oat, barley, rye grass and bajra Napier hybrid give higher fodder yield but are deficient in protein content while fodder legumes such as ricebean, phillipesara, soybean, cowpea, cluster bean etc., are rich sources of protein but their fodder yield is lower than cereal fodder (Iqbal et al., 2015).

The chronic shortage of feed and fodder resources during the last few decades indicate that most of the livestock were underfed. Thus, legume-cereal composition is considered as a management strategy to produce both high quality and quantity forage. Legumes, which are good source of protein, that can be intercropped with cereals to compensate their protein shortage (Eskandari, 2012). Non-legumes intercropped with legumes significantly increased the total mixed green forage yield and crude protein content of mixed forage (Iqbal et al., 2006). Thus efforts need to be made to intensify fodder productivity and production per unit area and time with good quality. Hence, the experiment was conducted to find out suitable cereal legume intercropping system for availability of good quality fodder with maximum yield.

\section{Materials and Methods}

The experiment was conducted during kharif season of 2018 at Zonal Agricultural Research Station, Vishweswaraiah Canal Farm, Mandya which is situated between $12^{\circ}$ $45^{\prime}$ and $13^{\circ} 57^{\prime}$ North latitude and $76^{\circ} 45^{\prime}$ and $78^{\circ} 24^{\prime}$ 'East longitude at an altitude of $695 \mathrm{~m}$ above mean sea level and comes under Southern Dry Zone (ACZ-VI) of Karnataka with mean annual rainfall of $735.9 \mathrm{~mm}$ with maximum contribution from south west monsoon (42.59\%). The soil of the experimental site was red sandy loam in texture having low in available nitrogen (265.4 kg/ha), medium in available phosphorus (49.25 kg/ha) and potassium $(162.35 \mathrm{~kg} / \mathrm{ha})$ with neutral in reaction. The experiment was laid out in randomized completely block design (RCBD) replicated three times with four sole crops viz., maize (African tall), sorghum (CO-FS 29), cowpea (MFC-09-1), bajra Napier hybrid (BNH-10) and three intercropping systems like maize + cowpea (3:1), sorghum + cowpea (3:1) and $\mathrm{BNH}+$ cowpea $(2: 8)$. The crops were raised as per the package of practices. Maize, sorghum and cowpea were harvested at 75, 70 and 50 days after planting while bajra Napier hybrid was harvested at 70 days after planting with subsequent harvest at 35 days interval. Immediately after harvest of the crops green fodder yield was recorded and known quantity of sample was taken and oven-dried for the estimation of dry matter as well as quality parameters. Quality parameters like crude protein (CP), crude fibre, ash and ether extractable fat percent age were determined by using standard procedure as recommended by AOAC (1984) and their respective yields were calculated by multiplying with dry matter yield of the crops. Total digestible crude protein yield (TDCPY) and non fibre carbohydrate (CHO) percentage was calculated by using following formula. 
TDCPY $=(0.97 \times$ crude protein yield $)-0.67$ Carbohydrates $(\%)=100-($ crude protein + fat + fibre + ash + moisture)

\section{Statistical analysis}

The data recorded for each parameter were subjected to statistical analysis adopting Fisher's method of analyses of variance as outlined by Gomez and Gomez (1984). The level of significance used in the $\mathrm{F}$ test was given at 5 per cent. Wherever the $\mathrm{F}$ test was significant, critical difference (CD) values are given in the table at 5 per cent level of significance.

\section{Results and Discussion}

\section{Green fodder yield and dry fodder yield}

Among different forage crops, significantly higher green and dry fodder yields were recorded in the $\mathrm{BNH}$ intercropped with cowpea (552.17 and $110.37 \mathrm{q} / \mathrm{ha}$, respectively) followed by maize intercropped with cowpea (445.43 and $91.41 \mathrm{q} / \mathrm{ha}$, respectively) but the later treatment was found statistically at far with sole BNH (435.7 and $86.78 \mathrm{q} / \mathrm{ha}$, respectively) when compared to other treatments (Table 1). Higher yields of the intercropping systems indicate the advantage of intercropping with cowpea over the sole crops. This higher green and dry fodder yields might be because intercropped cowpea have provided nitrogen through nitrogen fixation to the main crops which may have enhanced the production potential of the crops by promoting the growth parameters and fast accumulation of photosynthates in the sink. However significantly lower green and dry fodder yields were observed with sole fodder cowpea (252.33 and $49.96 \mathrm{q} / \mathrm{ha}$, respectively) might be due to lower fibre content and higher moisture content. Hindoriya et al., (2019) also found similar kind of higher yields with Napier bajra hybrid intercropped with cowpea. The results of the present study are in conformity with findings of Anita et al., (2015) and Aulakh et al., (2012).

\section{Quality parameters}

The higher dry matter (DM) content was observed with sole sorghum (22.97 \%) followed by sorghum intercropped with cowpea $(22.27 \%)$ which was statistically at for with each other (Table 1). This higher DM content was due to the presence of higher fibre content in the sorghum when compared to other crops. Similar kind of higher DM content $(23.6 \%)$ was also recorded by Iyanar et al., (2015). While, lower DM content was found with cowpea $(19.81 \%)$ and $\mathrm{BNH}$ (19.95 \%) may be due to more succulent shoots of these crops led to reduction in the DM content of crops.

The crude protein content was highest in sole fodder cowpea $(20.5 \%)$ followed by $\mathrm{BNH}$ intercropped with cowpea (17.75\%), maize intercropped with cowpea (12.03\%), sorghum intercropped with cowpea (11.07\%) while the lowest was recorded in sole sorghum $(8.23 \%)$. However BNH intercropped with cowpea recorded higher CPY (19.59 q/ha) and TDCPY (18.33 q/ha) followed by maize intercropped with cowpea (10.99 and $9.99 \mathrm{q} / \mathrm{ha}$, respectively) and sole fodder cowpea $(10.24$ and $9.26 \mathrm{q} / \mathrm{ha}$, respectively) while lower yields were recorded with sole sorghum (5.54 and 4.7 $\mathrm{q} /$ ha, respectively) (Figure 1). This lower yields might be due to lower $\mathrm{CP}$ content while higher yields with intercropping systems was attributed to higher dry matter yields. Similar kind of lower yields in sorghum was also reported by Kushwaha et al., (2018). Asangla and Gohain (2016) also opinioned that a considerable proportion of nitrogen was available to non-legume crops in the mixtures compared to pure stands and more crude 
protein content was because of more uptake of nitrogen which is a important constituent of protein, amino acids and amides.

The higher total ash content and total ash yield was recorded in $\mathrm{BNH}$ intercropped with cowpea (11.53\% and 12.73 q/ha, respectively) followed by maize intercropped with cowpea (10.68\% and 9.76 q/ha, respectively) compared to other treatments. However, the lower ash content was observed in sole sorghum $(8.21 \%)$ and sorghum intercropped with cowpea $(10.68 \%)$ this might be attributed to the higher DM content of sorghum compared to other fodder crops while lower ash yield was noticed in cowpea $(5.15 \mathrm{q} / \mathrm{ha})$ that was mainly due to lower drymatter yield of crop (Table 2 and Figure 2 ). The ether extractable fat content was highest in sorghum intercropped with cowpea (3.27\%) followed by $\mathrm{BNH}$ intercropped with cowpea $(3.02 \%)$ but the later one was found on far with sole sorghum $(2.98 \%)$ while lower value was recorded with sole maize
(2.48\%). The higher values were attributed to higher nitrogen uptake as it is positively correlated with ether extractable fat. However, the higher ether extractable fat yield was recorded in $\mathrm{BNH}$ intercropped with cowpea (3.33 q/ha) followed by maize intercropped with cowpea (2.77 q/ha). Similar kind of higher ether extractable fat yield in Napier bajra hybrid intercropped with cowpea was also reported by Hindoriya et al., (2019).

Among the different treatments, higher crude fibre content was recorded in sole sorghum (34.17\%) followed by sorghum intercropped with cowpea $(32.05 \%)$ and maize $(31.9 \%)$ while lower values were recorded with sole cowpea $(27.83 \%)$ and $\mathrm{BNH}$ intercropped with cowpea (27.88\%) (Table 2). This lower fibre content might be attributed to succulent nature of these crops led to reduction in the fibre content of crops. Similar kind of highest amount of crude fibre content in pure stand of forage sorghum $(41.22 \%)$ was also reported by Reza et al., (2012).

Table.1 Green fodder yield (GFY), dry matter yield (DMY) and drymatter percentage

\begin{tabular}{|c|c|c|c|}
\hline Treatments & GFY (q/ha) & DM (\%) & DMY (q/ha) \\
\hline Sole Maize & $343.5 \mathrm{~d}$ & $20.82 \mathrm{~b}$ & $71.54 \mathrm{~d}$ \\
\hline Sole Sorghum & $292.5 \mathrm{e}$ & $22.97 \mathrm{a}$ & $67.23 \mathrm{~d}$ \\
\hline Sole Cowpea & $252.33 \mathrm{f}$ & $19.81 \mathrm{~b}$ & $49.96 \mathrm{e}$ \\
\hline Sole BNH & $435.17 \mathrm{~b}$ & $19.95 \mathrm{~b}$ & $86.78 \mathrm{bc}$ \\
\hline Maize + cowpea (3:1) & $445.43 \mathrm{~b}$ & $20.54 \mathrm{~b}$ & $91.41 \mathrm{~b}$ \\
\hline Sorghum + cowpea (3:1) & $380.67 \mathrm{c}$ & $22.27 \mathrm{a}$ & $84.72 \mathrm{c}$ \\
\hline BNH + cowpea (2:8) & $552.17 \mathrm{a}$ & $19.99 \mathrm{~b}$ & $110.37 \mathrm{a}$ \\
\hline LSD (P=0.05) & 31.48 & 1.01 & 6.31 \\
\hline SEm \pm & 10.21 & 0.33 & 2.05 \\
\hline
\end{tabular}

Note: Values with different alphabets are significantly differ with each other and values with same alphabets are non significant 
Table.2 Quality parameters of fodder as influenced by cereal-legume intercropping systems

\begin{tabular}{|c|c|c|c|c|}
\hline Treatments & Ash (\%) & Fat (\%) & Fibre (\%) & CHO (\%) \\
\hline Maize & $10.22 \mathrm{~b}$ & $2.48 \mathrm{c}$ & $31.9 \mathrm{~b}$ & $32.72 \mathrm{ab}$ \\
\hline Sorghum & $8.21 \mathrm{~d}$ & $2.98 \mathrm{~b}$ & $34.17 \mathrm{a}$ & $34.43 \mathrm{a}$ \\
\hline Cowpea & $10.30 \mathrm{~b}$ & $2.65 \mathrm{c}$ & $27.83 \mathrm{~d}$ & $25.93 \mathrm{c}$ \\
\hline BNH & $10.3 \mathrm{~b}$ & $2.98 \mathrm{~b}$ & $30.15 \mathrm{c}$ & $34.43 \mathrm{a}$ \\
\hline Maize + cowpea (3:1) & $10.68 \mathrm{~b}$ & $2.65 \mathrm{c}$ & $30.17 \mathrm{c}$ & $32.15 \mathrm{~b}$ \\
\hline Sorghum + cowpea (3:1) & $8.92 \mathrm{c}$ & $3.27 \mathrm{a}$ & $32.05 \mathrm{~b}$ & $32.35 \mathrm{~b}$ \\
\hline BNH + cowpea (2:8) & $11.53 \mathrm{a}$ & $3.02 \mathrm{ab}$ & $27.88 \mathrm{~d}$ & $26.70 \mathrm{c}$ \\
\hline LSD (P=0.05) & 0.56 & 0.28 & 1.29 & 1.83 \\
\hline SEm \pm & 0.18 & 0.09 & 0.42 & 0.59 \\
\hline
\end{tabular}

Note: Values with different alphabets are significantly differ with each other and values with same alphabets are non significant

Fig.1 Crude protein content, Crude protein yield and TDCPY of fodder as influenced by cereallegume intercropping systems

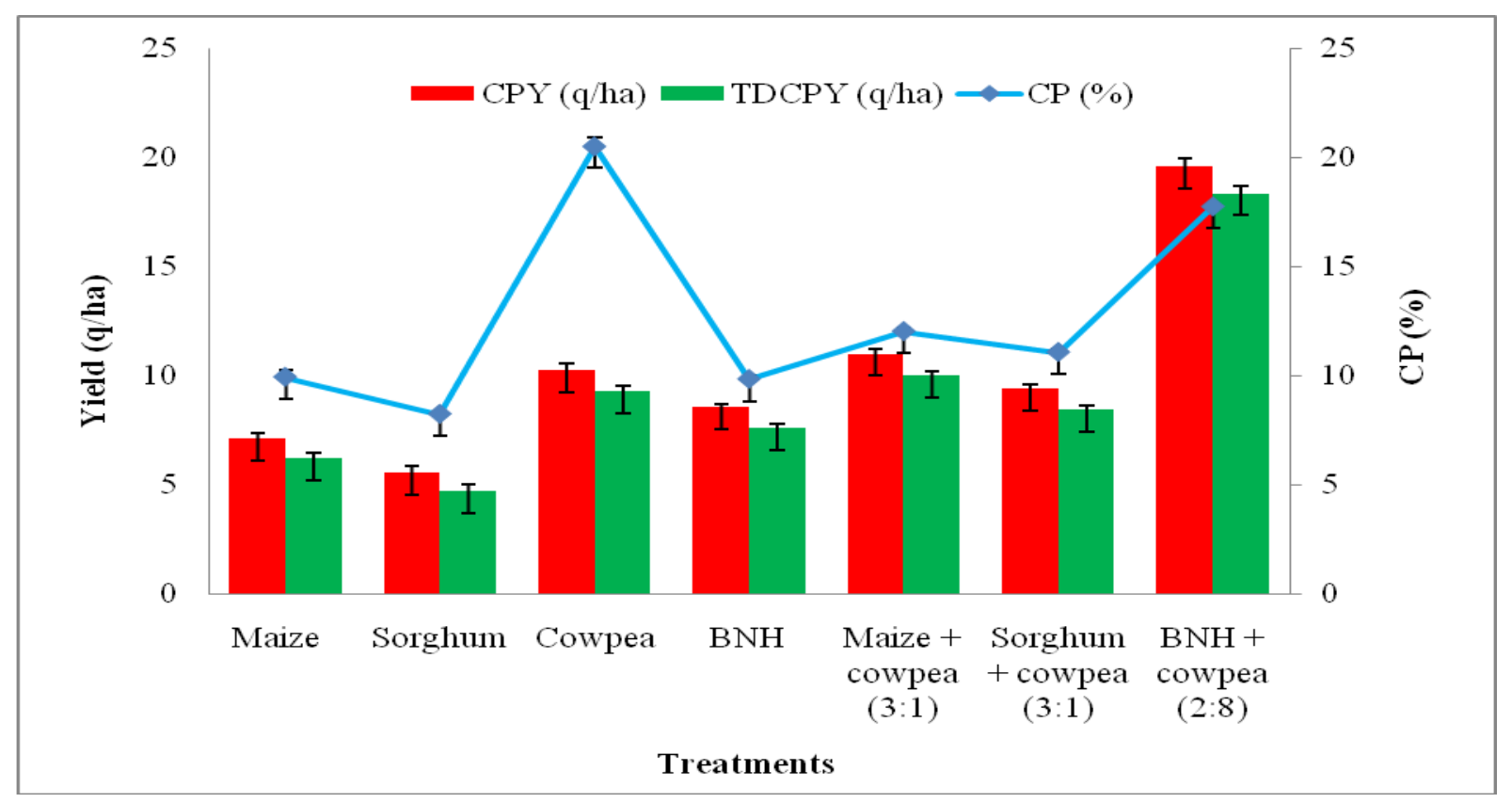


Fig.2 Quality parameters yield of fodder as influenced by cereal-legume intercropping systems
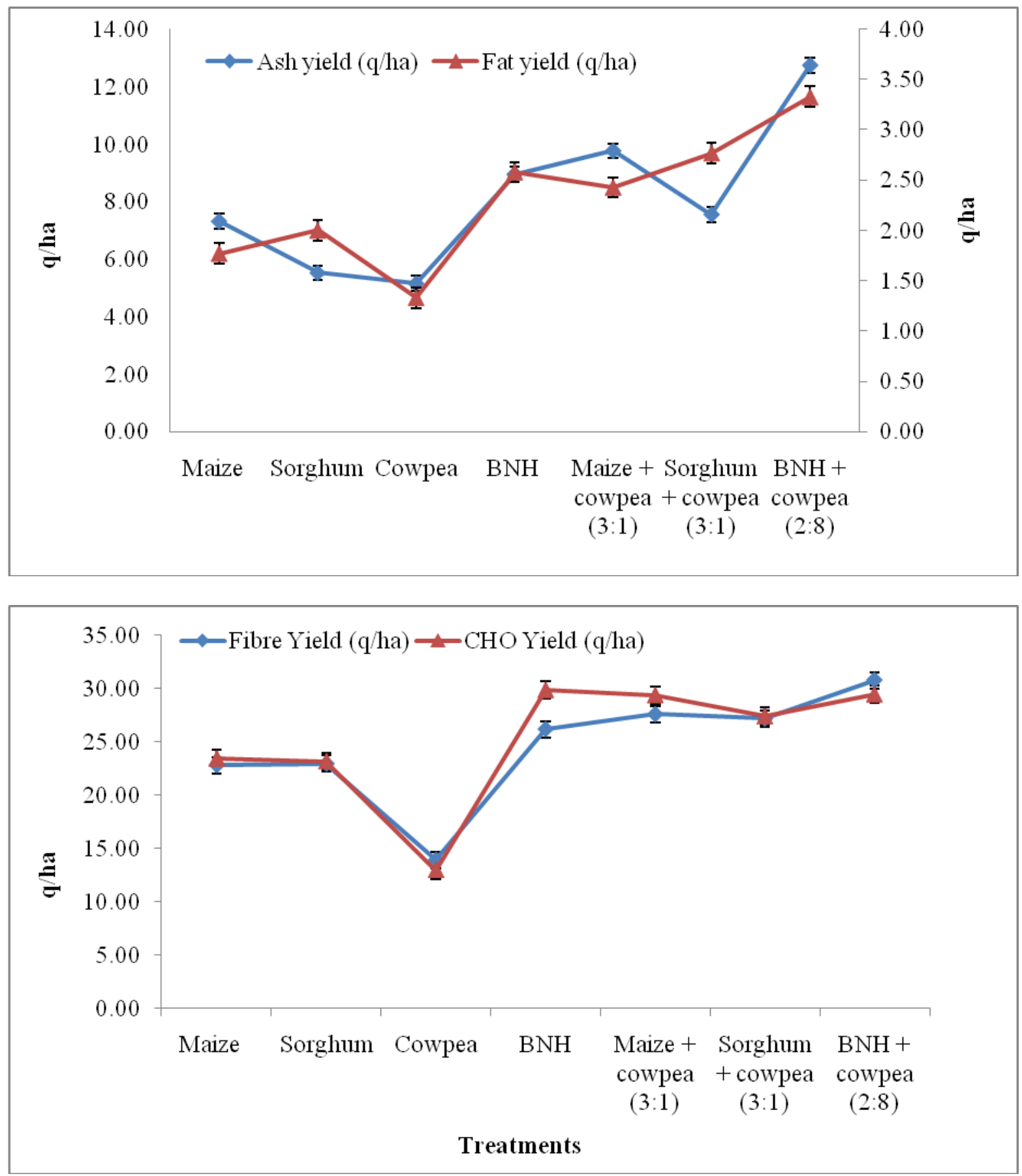

The higher non-fibre carbohydrate content was recorded in sole cereal crops like sorghum $(34.43 \%)$ and $\mathrm{BNH}(34.43 \%)$ followed by maize $(32.72 \%)$ while lower carbohydrate content was noticed in sole cowpea $(25.93 \%)$ and $\mathrm{BNH}$ intercropped with cowpea (26.70\%) (Table 2). This might be attributed to the higher values of above 
mentioned quality parameters of the fodder crops. On the other hand, higher non-fibre carbohydrate yield was found in sole $\mathrm{BNH}$ (29.87 q/ha) followed by BNH intercropped with cowpea $(29.46 \mathrm{q} / \mathrm{ha})$ and maize intercropped with cowpea (29.39 q/ha) which was mainly due to higher drymatter yields while lower carbohydrate yield was recorded in sole cowpea (12.94 q/ha) (Figure 2).

In this study intercropping systems resulted in higher green and dry fodder yields compared to sole crops. Similarly higher yield of quality parameters also observed in the same intercropping systems compared to sole crops. Among the intercropping systems, $\mathrm{BNH}$ intercropped with cowpea at the row ratio of 2:8 performed well both in terms of quantity and quality of fodder.

\section{Acknowledgment}

The authors are grateful to authority of Department of Science and Technology, New Delhi for providing financial assistance for execution of experiment.

\section{References}

Anita, M.R., Lakshmi, S. and Rani, T.S., 2015. Effect of row ratios of grass fodder cowpea mixtures on the yield and quality of forages. Int. J. Forestry Crop Improv., 6: 85-89.

AOAC., 2005. Official Methods of Analysis. $18^{\text {th }}$ edn. Association of Official Analytical Chemists. Arlington, Virginia, USA.

Asangla, H.K. and Gohain, T., 2016. Effect of fodder yield and quality attributes of maize (Zea mays L.) + cowpea (Vigna unguiculata L.) intercropping and different nitrogen levels. Int. J. Agric. Sci. Res., 6: 349-356.

Aulakh, C.S., Gill, M.S., Mahey, R.K., Walia, S.S. and Singh, G., 2012. Effect of nutrient sources on productivity of fodder cropping systems in Punjab. Indian J. Agron., 57: 200-205.

Eskandari, H., 2012. Intercropping of maize (Zea mays) with cowpea (Vigna sinensis) and mungbean (Vigna radiata): Effect of complementarity of intercrop components on resource consumption, dry matter production and legumes forage quality. J. Basic Appl. Sci. Res., 2(1): 355-360.

Gomez, K.A. and Gomez, A.A., 1984. Statistical Procedure for Agriculture Research, $2^{\text {nd }}$ Ed., John Willey and Sons, New Yark. pp. 680.

Hindoriya, P.S., Kumar, M.R., Magan, S., Rakesh, K., Hardev, R., Kumar, M.V. and Manish, K., 2019. Evaluation of kharif forage crops for biomass production and nutritional parameters in Indo-Gangetic plains of India. Indian J. Anim. Nutr., 36: 25-29.

Iqbal, A., Ayoub, M. Zaman, H. and Ahmad, R., 2006. Impact of nutrient management and legume association on agro-qualitative traits of maize forage. Pakistan J. Botany, 38(4): 1079-1084.

Iqbal, M.A., Iqbal, A.A., Raza, A.Z. and Faizal, N., 2015. Over viewing forage maize yield and quality attributes enhancement with plant nutrition management. World J. Agric. Sci., 11: 128-134.

Iyanar, K., Babu, C., Kumaravadivel, N., Kalamani, A., Velayudham, K. and Sathia Bama, K., 2015. A high yielding multicut fodder sorghum $\mathrm{CO} 31$. Electron. J. Plant Breeding, 6(1): 5457.

Kushwaha, M., Singh, M., Kumar, R., Tyagi, N., Soni, P.G., Choudhary, S. and Makarana, G., 2018. Yield and quality of multicut fodder sorghum as affected by nutrient levels and biofertilizer application. Indian J. Anim. Nutr., 35: 82-89. 
Reza, Z.O., Allahdadi, I., Mazaheri, D., Akbari, G.A., Jahanzad, E. and Mirshekari, M., 2012. Evaluation of quantitative and qualitative traits of forage sorghum and lima bean under different nitrogen fertilizer regimes in additive - replacement series. J. Agric. Sci., 4(6):223 - 235 .

\section{How to cite this article:}

Manoj, K.N., B.G. Shekara and Shoba, D. 2020. Production Potential and Forage Quality of Cereal-Legume Intercropping Systems in Cauvery Command Area of Karnataka. Int.J.Curr.Microbiol.App.Sci. 9(05): 3175-3182. doi: https://doi.org/10.20546/ijcmas.2020.905.377 